\title{
NEW SASKATCHEWAN BUTTERFLY RECORDS
}

\author{
by Ronald R. Hooper, Fort Qu'Appelle
}

During an insect-collecting fieldrip for the Saskatchewan Museum of vatural History from June 24 to 29, 968, I collected four new butterfly pecies for Saskatchewan, three of hich are new species for Canada. he collecting was done in the badands along the Frenchman River in he western part of the Wood Mounains.

The barren hilltops are a semiesert environment which is the only lace in Saskatchewan where the Horned Lizard has been found. The at areas near the river contain the amous Prairie Dog colonies.

Collecting is difficult on the hilltops ecause of the almost constant breeze. the best time to collect seems to be n sunny mornings before the sun ecomes too hot or the wind too trong. The butterflies congregate on he sunny, sheltered sides of the lopes around the flowers of Yellow Imbrella Plant (Eriogonum flavum), enecio, and various Leguminosae. bollecting must be done by careful talking, for once the insect is alarm$d$ there is little hope of following it $n$ such rugged terrain, especially if breeze catches it. For this reason here are probably many more species lew to Saskatchewan yet to be disovered in this type of area.

The day-by-day collecting went as ollows-

IONDAY, June 24-We drove to killdeer, but found it too wet to go nto the Killdeer badlands, so we eaded toward Val Marie.

UESDAY, JUNE 25-Collected in horning in badlands northeast of $\mathrm{Val}$ Iarie, where I took Canada's first ecord of Oslar's Roadside Skipper Amblyscirtes oslari Skin.). One specihen was taken in this locality and ne other specimen was taken in the fternoon on a hilltop southeast of al Marie. This species has been ormerly recorded as ranging north - Nebraska.

WEDNESDAY, JUNE 26-We drove to the badlards on the east side of the Frenchman River, east of Rosefield, within a mile or so of the Montana border. The day was cool and windy, and the sun did not shine until late in the afternoon when I went up on a barren hilltop, where I collected Saskatchewan's first record of Alpine (or Colorado) Blue (Philotes battoides centralis B. \& McD.). The closest former record was a specimen that I took at Elkwater, Alberta in June, 1963.

THURSDAY, JUNE 27-A beautiful day. While on the way up a junipercovered slope, I netted a small, faded hairstreak on a Senecio blossom. It turned out to be a Juniper Hairstreak (Mitoura siva Edw.). The closest previous record for this species is western North Dakota. It has not been recorded before for Canada.

Later in the morning I took a-single fresh specimen of Simius Roadside Skipper (Amblyscirtes simius Edw.). This too is Canada's first record. It has been recorded as occurring north to Nebraska.

FRIDAY, JUNE 28-I collected in the Wood Mountain Regional Park area, but came up with nothing new. This is rather to be expected, as it is on the northern slopes and therefore is not in the Missouri drainage. It seems to be typical parkland in many ways.

SATURDAY, JUNE 29-I collected in the badlands southwest of Killdeer, but the weather was very poor and not much was taken.

These specimens were identified by C. F. Dos Passos of Mendham, N.J.

I should also like to report at this time that C. F. Dos Passos has identified for me as well a specimen of Juvenal's Dusky Wing (Erynnis juvenalis Fab.) which I took among the Bur Oak in June, 1967. This is Saskatchewan's first authentic record of Juvenal's Dusky Wing. It brings the list of definitely determined Saskatchewan butterflies to 118 species. 